\title{
ANALISIS APLIKASI BILLING RENTAL PLAYSTATION \\ PADA CLASSIC PLAYSTATON MENGGUNAKAN VISUAL.NET
}

\author{
Rini Malfiany \\ STMIK Rosma, Sistem Informasi \\ E-mail: rini@rosma.ac.id \\ J1. Kertabumi No.62 Karawang 41311
}

\begin{abstract}
Abstraksi
Salah satu tuntutan yang dihadapi dunia industri jasa saat ini adalah menciptakan sistem pelayanan terhadap publik yang memberikan kemudahan dalam tukar-menukar informasi, transaksi, dengan tingkat keamanan yang baik dan biaya yang murah.

Metode yang digunakan dalam penulisan meliputi metode deskriptif yang menggambarkan tentang sistem yang akan dibuat, dan metode eksperimental yang dilakukan dengan cara mencoba cara kerja sistem

Pada Penulisan Ilmiah ini penulis mencoba untuk membahas analisis aplikasi billing yang berhubungan dengan kegiatan operasional suatu rental playstation yang mencakup tentang penghitungan waktu, penghitungan biaya, serta pembuatan laporan transaksi.

Dari gambaran tersebut d iatas, dapat diambil kesimpulan bahwa untuk membangun suatu badan usaha diperlukan adanya sistem yang mempermudah transaksi antara penyedia jasa dan pengguna jasa. Dan aplikasi billing merupakan salah satu solusi untuk mengatasi permasalahan tersebut. Saran yang membangun sangat penulis harapkan untuk kesempurnaan penulisan ini.
\end{abstract}

\section{Kata Kunci : Billing Rental Playstation}

\section{PENDAHULUAN}

Perkembangan teknologi yang sangat pesat di bidang penyedia jasa layanan Internet dengan akses yang cepat dan dengan biaya yang cukup relative murah memunculkan banyak orang untuk mendirikan usaha kecil dengan membangun warung internet.

Warung Internet merupakan peluang usaha yang menggiurkan yang bisa mendatangkan keuntungan yang sangat besar dan tentunya memerlukan investasi awal yang besar pula. Banyak hal yang harus dipersiapkan mulai dari tempat/lokasi yang bisa dipandang baik dari segi ekonomi, hardware, software, dan aplikasi yang bisa membantu dalam pengelolaan segala transaksi. dalam memulai usaha ini.

Untuk membantu pengoperasian usaha warung internet ini, tentunya memerlukan suatu perangkat yang bisa membantu dalam penghitungan waktu ataupun biaya yang dipakai atau yang sering disebut dengan Billing/Tagihan.

Aplikasi billing rental playstation ini mempunyai tujuan untuk kemudahan dalam pengontrolan komputer yang terhubung dalam jaringan, menerima semua koneksi dari komputer yang ada di komputer client serta menyimpan ringkasan data dan menampilkan laporan pendapatan.

\section{$\mathbf{5 8}$ | B u a n a I $1 \mathrm{~m}$ u}


Adapun manfaat yang diperoleh dari penyusunan ilmiah adalah memberikan kemudahan bagi perusahaan untuk pengelolaan jaringan komputer dan internet serta kemudahan dalam pengontrolan transaksi dengan konsumen juga memberikan kenyamanan, keamanan dan keakuratan data.

Metode penelitian yang digunakan dalam Penulisan ilmiah ini adalah

1. Metode Deskriptif dan Eksperimental

Dengan metode tersebut penulis dapat menggambarkan tentang masalah yang akan diselidiki/diteliti secara aktual dan melakukan percobaan cara kerja sistem yang akan dibuat

2. Metode Filosofis

Dengan metode ini kiranya penulis mampu memecahkan masalah melalui pemikiran yang terarah, mendalam dan mendasar dalam penulisan ilmiah ini.

\section{LANDASAN TEORI}

\subsection{Definisi Billing}

Billing menurut https://id.wikipedia.org/wiki/Sistem_Billing (23 Pebruari 2019) berasal dari bahasa Inggris yaitu bill, yang artinya bukti transaksi pembayaran. Maka, billing dapat juga diartikan mengirimkan bukti transaksi, atau mengumumkan bukti transaksi. Billing rental adalah sebuah software atau aplikasi komputer yang berfungsi sebagai mesin pencatat waktu pemakaian rental. Untuk mempermudah pemahaman fungsi dari billing rental adalah sebagai mesin kasir atau mesin transaksi digital.

\subsection{Definisi Sistem Billing}

Setiap bidang usaha kini selalu melakukan transaksi, apalagi bidang-bidang yang selalu melakukan transaksi dalam jumlah besar seperti rumah sakit atau departement store atau bidang usaha yang transaksinya berbentuk abstrak seperti usaha rental playstation disinilah sistem billing bekerja. Sistem billing merupakan sistem yang membantu para usahawan untuk mengatur dan mencatat segala transaksi yang terjadi. Contohnya bagi pengusaha rental playstation, billing sistem digunakan untuk memonitor penggunaan dan pemasukan rentalnya. Sedangkan jika bagi usahawan di bidang rumah sakit sistem billing digunakan untuk mencatat proses pelayanan, mulai pasien datang sampai dengan pasien pulang. Menghitung biaya yang harus dibayar pasien secara otomatis, serta memberikan informasi sebagai analisa pengambilan keputusan secara cepat dan akurat.

\subsection{Bentuk Sistem Billing}

Pada dasarnya sistem billing merupakan sistem pencatat dan pemonitor transaksi berbentuk software. Sistem jaringan komputer billing system merupakan aplikasi yang terintegrasi, sehingga komputer-komputer yang ada (server dan workstation) harus dihubungkan dengan menggunakan topologi star. Dengan sistem jaringan komputer ini operasional ataupun proses monitoring dapat dilakukan dari mana sesuai hak akses masingmasing pengguna.

\subsection{Kemampuan Sistem Billing}

1. Penggunaan setiap workstation (klien)

2. Pendapatan total rental per hari

3. Jumlah pengguna rental per hari dan beberapa fitur lainnya. 


\subsection{Perangkat pendukung}

Dalam mengoperasikan sistem billing ini tidak hanya cukup memiliki software dan juga komputer tempat mengoperasikannya. Perangkat lain yang dibutuhkan ada bermacam-macam. Tetapi perlu diingat bahwa tiap bidang usaha dan juga sistem yang digunakan berbeda-beda kebutuhannya. Komputer billing system termasuk dalam sistem billing game biliar merupakan aplikasi yang terintegrasi, sehingga komputer-komputer yang ada (server dan workstation) harus dihubungkan dengan menggunakan topologi star. Dengan sistem jaringan komputer ini operasional ataupun proses monitoring dapat dilakukan dari mana sesuai, sesuai hak akses masing-masing pengguna. Perangkat yang terpenting dari semuanya adalah sumber daya manusia yang terampil dan disiplin dan juga jujur sehingga sistem dapat berjalan sesuai dengan yang diinginkan.

\section{METODOLOGI PENELITIAN}

\subsection{Metode Pengumpulan}

Metode pengumpulan data yang digunakan dalam penelitian jurnal ilmiah yang akan dilakukan adalah sebagai berikut Observasi, Library Research, metode deskripsi dan eksperimental.

\subsection{Prosedur yang sedang berjalan}

1. tipe jaringan : Rental Classic Playstation menggunakan model konfigurasi LAN sebagai tipe jaringannya karena hanya sebatas pada area yang relative kecil.

2. Media penghubung : Menggunakan media kabel UTP Cat5 sebagai penghubung antara satu komputer dengan komputer lainnya,

3. Topologi jaringan : Menggunakan topologi jaringan bintang/star

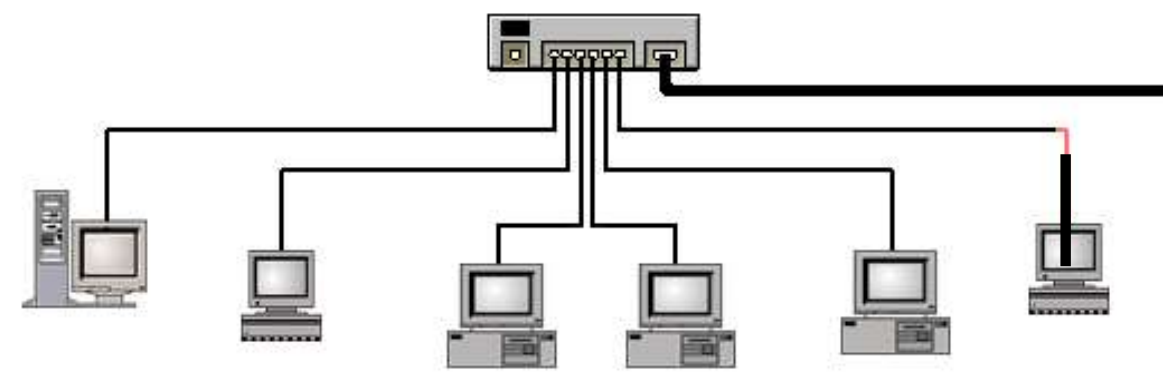

Gambar 3.1 Instalasi jaringan Rental Classic Playstation

4. Sistem jaringan : Sistem Peer to Peer/workgroup digunakan dalam pengelolaan jaringannya, yang mana satu computer dengan computer yang lain mempunyai kemampuan dan hak yang sama.

5. Sistem Operasi yang digunakan : Rental PS menggunakan sistem operasi berbasis windows 101 pada computer server maupun di semua computer clientnya.

6. Penghitung waktu dan biaya : Rental PS mempunyai sebuah aplikasi yang bisa membantu operator dalam penghitungan waktu dan biaya atau sering disebut dengan billing sistem, billing sistem yang ada di Renral PS ini menggunakan Billing yang sederhana, adapun fiturfitur yang dimiliki Billing Sistem ini terdiri dari dua bagian menu utama, yang pertama Monitor PC Client yang bisa digunakan untuk memantau waktu dan biaya yang harus dikeluarkan pengguna jasa rental, dan yang kedua menu konfigurasi yang bisa digunakan sebagai pengaturan/perubahan data. 


\subsection{Monitor PC Client}

Menu pada tampilan monitor PC client menampilkan :

1. Station : Station ini menunjukan initial PC Client yang dibedakan menurut IP address

2. Status : Status menunjukan kondisi PC Client, yang terdiri dari Idle (Stand by), Running (Mulai), Stop (Selesai)

3. Awal/Akhir : Menunjukan kondisi waktu pada saat PC Client mulai digunakan dan selesai digunakan

4. Pemakaian : Pemakaian menunjukan durasi yang telah dipakai pada pada saat PC Client digunakan

5. Biaya : Biaya menunjukan berapa rupiah yang harus dikeluarkan pelanggan setelah selesai menggunakan PC

6. Internet : Menunjukan status pelanggan dalam menggunakan PC yang menggunakan layanan internet

7. Member : Menunjukan pelanggan yang sudah terdaftar menjadi anggota

8. Renthal : Menunjukan status pelanggan yang menggunakan sistem paket

9. Reset : Tombol reset digunakan untuk mengembalikan billing ke posisi awal

10. Selesai : Tombol selesai digunakan untuk mengakhiri perhitungan waktu dan biaya serta dengan petunjuk perbedaan warna merah pada kolom station

11. Mulai : Tombol mulai digunakan untuk memulai menjalankan perhitungan waktu dan biaya dan ditunjukan dengan perbedaan warna hijau pada kolom station

\subsection{Configuration}

Menu configuration dipergunakan untuk pengaturan/perubahan data billing system yang terdiri dari :

1. Station : Station digunakan untuk pengaturan jumlah PC client yang akan digunakan

2. Nama Rental : Nama rental berfungsi sebagai identitas rental

3. Cetak ke Printer : Bagian ini digunakan untuk pilihan menampilkan hasil laporan transaksi apakah akan dicetak atau tidak

4. Internet : Bagian ini berfungsi sebagai pengaturan biaya yang disesuaikan dengan waktu penggunaan dalam hitungan menit

5. Member : Bagian ini berfungsi sebagai pengaturan biaya yang disesuaikan dengan waktu penggunaan dalam hitungan menit

6. Renthal : Bagian ini berfungsi sebagai pengaturan biaya yang disesuaikan dengan waktu penggunaan dalam hitungan menit

7. Unlock : Bagian ini digunakan untuk membuka pengaturan perubahan data

8. Save Config : Tombol ini digunakan untuk menyimpan perubahan pengaturan data

\subsection{Permasalahan yang Dihadapi}

Setelah melakukan analisa terhadap system atau prosedur yang berjalan khususnya pada sistem Billing rental classic playstation, penulis menemukan beberapa kelemahan/kekurangan pada sistem billing yang ada diantaranya adalah sebagai berikut :

1. Informasi yang ada pada billing sistem hanya sebatas perhitungan yang disimpan pada komputer server saja dan tidak ada informasi yang bisa dilihat di komputer client 
2. Perhitungan waktu tidak akurat

\subsection{Rancangan Solusi Pemecahan Masalah}

Solusi pemecahan masalah dari kelemahan yang terdapat pada sistem billing yang ada di Rental Playstation diantaranya adalah :

1. Merancang aplikasi billing sistem Client - Server

2. Merancang billing sistem yang bisa menampilkan waktu yang akurat.

\section{HASIL DAN PEMBAHASAN}

\subsection{Usulan Prosedur Yang Baru}

Rancangan aplikasi billing client-server terdiri dari dua bagian utama, yang pertama aplikasi yang dipasang pada server dan mempunyai sebuah aplikasi penyimpanan database, dan aplikasi yang kedua dipasang pada masing-masing komputer client.

Pada sisi client, aplikasi billing menjalankan fungsi-fungsi sebagai berikut:

1. Login client, fungsi ini digunakan pelanggan untuk memulai pemakaian pada komputer client.

2. Setting, fungsi ini digunakan untuk mengatur koneksi dari client ke server.

3. Monitoring waktu dan biaya, fungsi ini digunakan untuk mengetahui pemakaian waktu dan penghitungan biaya

Sedangkan pada server, aplikasi billing menjalankan fungsi-fungsi sebagai berikut :

1. Login server, fungsi ini diberikan kepada operator dan administrator agar yang tidak mempunyai hak akses tidak bias masuk ke dalam system.

2. Kirim pesan ke client, fungsi ini diberikan kepada operator dan administrator untuk mengirim pesan ke client.

3. Memantau client, fungsi ini diberikan kepada operator dan administrator untuk menampilkan seluruh koneksi client dan proses transaksi bagi client yang masih aktif terkoneksi.

4. Pengaturan database, fungsi ini digunakan administrator untuk melakukan perubahan data tarif.

5. Client Logout, fungsi ini digunakan sebagai informasi kepada administrator bahwa client telah logout dan data biaya yang harus dibayar pelanggan.

6. Cetak transaksi, fungsi ini digunakan untuk mencetak laporan transaksi.

\subsection{Pengujian program}

Setelah program yang dirancang selesai kemudian diuji dengan cara memasukkan data yang ada kemudian dicatat kecepatan kerjanya lalu bandingkan kecepatan kerja denganSistem yang sudah berjalan

\subsection{Pemasangan program}

Untuk mengimplementasikan sistem yang telah dibuat dibutuhkan fasilitas dan peralatan yang mendukung beroperasinya system tersebut, karena sistem baru ini hanya berjalan jika didukung fasilitas dan peralatan seperangkat komputer.

1. Perangkatkeras (hardware) diantaranya personal komputer, monitor dan printer. 
2. Perangkatlunak (software) diantaranyasistemoperasi windows.

3. Bahasa pemrograman visual.net dan program aplikasi sistem database.

\section{KESIMPULAN DAN SARAN}

Setelah penulis membuat Billing Sistem, maka penulis dapat memberikan kesimpulan secara menyeluruh tentang pembuatan aplikasi Billing Sistem sebagai berikut :

1. Aplikasi Billing sistem memerlukan sebuah Bahasa pemrograman Visual.Net sebagai media dalam pembuatan aplikasinya.

2. Aplikasi Billing Sistem ini merupakan aplikasi Client - Server sehinnga data yang ada pada PC Client selalu Update dengan PC Server.

\section{DAFTAR PUSTAKA}

Hidayatulah, Priyanto. (2015) Visual Basic.Net. Bandung: Informatika

Azzaky, Gamma Habie, dkk. (2016). Perencanaan Sistem Informasi Berbasis Web Untuk Sistem Persediaan Dan Sistem Pemesanan Produk Jadi Konveksi Seragam Pada PD.Devi Khusus. ISSN: 2355-9365. Vol.3 No.2. Hal 2788-2794.

Fathansyah. (2012). Basis Data (Edisi Revisi). Bandung: Informatika.

Hadi, Ahmodul. (2016). “Administrasi Jaringan Komputer”. Jakarta: Kencana.

Hutahaean, Japerson. (2014). “Konsep Sistem Informasi”. Yogyakarta: Deepublish.

Indrajani. (2011) "perancangan Basis Data dalam All in 1". Jakarta: PT Elex Media Komputindo.

Kadir, Abdul. (2014). Pengenalan Sistem Informasi Edisi Revisi. Yogyakarta: Andi.

Lubis, Adyanata. (2016). “Basis Data Dasar”. Yogyakarta: Deepublish

Mulyani, Sri. (2016)“Metode Analisis dan Perancangan Sistem”. Bandung: Abdi Sistematika.

Mustakini, Jogiyanto Hartono. (2010). Analisa Sistem Informasi, Edisi III. Yogyakarta: Andi.

Pamungkas, Canggih Ajika. (2017). “Pengantar dan Implementasi Basis Data”. Yogyakarta: Deepublish.

Pressman, Roger S. (2012). Rekayasa Perangkat Lunak Pendekatan Praktisi (Edisi 7). Yogyakarta: Andi. 